\title{
PERANAN PERSONAL HYGIENE DALAM MENINGKATKAN KUALITAS MAKANAN DI RESTAURANT HOTEL KARTIKA WIJAYA BATU
}

\author{
Sucia Arika Isnainy Qadarin ${ }^{1}$ \\ Muhammad Danang Setioko ${ }^{2}$ \\ Program Diploma Kepariwisataan Universitas Merdeka Malang1 \\ Jl. Bandung No. 1 Malang
}

Korespodensi dengan Penulis:

Muhammad Danang Setioko: Telp: 6281333407709

E-mail: dmudas@gmail.com

\begin{abstract}
The purpose of this study was to clarify the role of personal hygiene in improving the quality of food at the Restaurant Hotel Kartika Wijaya. This research is a descriptive study using a qualitative approach. The population in the study of 10 respondents. Data collection techniques were used that observation and questionnaires. Data from the research showed that many employees in the kitchen at the Hotel Kartika Wijaya not apply personal hygiene. Therefore contributes to the quality of food at the Restaurant Hotel Kartika Wijaya .
\end{abstract}

Keywords : Personal Hygiene, Quality Foods

Keberadaan sektor persaingan di bidang perhotelan pariwisata pada saat ini merupakan pada era globalisasi ini. Disamping salah satu aset terbesar bagi negara. itu juga, hotel harus mampu Terutama di bidang industri memberikan pelayanan yang terbaik perhotelan khususnya, sebagai sarana yang menyediakan segala bagi tamunya.

Kemantapan pelayanan suatu kebutuhan tamu, hotel harus dapat hotel terlihat dari tingkat hygiene meningkatkan kualitas produk dan jasanya seiring dengan ketatnya personalnya seta departementdepartement pendukung hotel 
lainnya.

Didalam

upaya

meningkatkan pelayanan hotel, salah satu departement yang mempunyai peran penting dalam fungsinya adalah bagian dapur atau kitchen departement.

Dapur hotel merupakan salah satu bagian hotel yang tugas utamanya adalah mengolah makanan. Kesehatan dan kebersihan dapur adalah merupakan kunci keberhasilan dari seluruh tugas dalam melaksanakan bidang food production and preparation. Karena pentingnya penerapan hygiene personal pada kebersihan dan kesehatan pada diri sendiri.

Menurut

Departemen

Kesehatan RI Malang (2000:3)

"Kualitas makanan berhubungan dengan tingkat keistimewaan, sifat, karakter, fungsi atau ciri-ciri yang menunjukkan kesehatan bahwa makanan atau bahan makanan serta produk olahannya untuk tujuan yang dimaksudkan dan tergantung pada kaitan permasalahannya sejak bahan diterima dititik proses manufakturing distribusi atau maksud lain yang menyertainya.
Dalam kehidupan sehari-hari kebersihan merupakan hal yang sangat penting dan harus diperhatikan karena kebersihan akan mempengaruhi kesehatan dan psikis seseorang. Khusus untuk karyawan dapur lebih diutamakan untuk memakai alat kerja yang lengkap dan sesuai dengan prosedur kerja guna untuk menghindari kecelakaan kerja dan terkontaminasinya makanan pada bakteri dan bibit penyakit. Dengan demikian, seluruh karyawan hotel telah turut serta dan peduli terhadap kebersihan, kesehatan dirinya.

Menurut Departement Kesehatan adalah salah satu kemampuan dasar manusia dalam memenuhi kebutuhannya guna mempertahankan kehidupannya, kesehatan dan kesejahteraan sesuai dengan kondisi kesehatannya karyawan dinyatakan terganggu keperawatan dirinya jika tidak dapat melakukan perawatan diri (Depkes 2000).

Personal Hygiene berasal dari bahasa Yunani yaitu personal yang artinyaperorangan dan Hygiene 
berarti sehat. Kebersihan seseorang adalah suatu tindakan untuk memelihara kebersihan dan kesehatan seorang untuk kesejahteraan fisik dan psikis (Hidayat, Agung 2009).

Personal Hygiene adalah faktor yang sangat penting karena diri kita merupakan penghantar vektor penyakit dan dalam makanan merupakan penyebab penyakit. Kebersihan diri adalah masalah serius dan harus menjadi perhatian bagi setiap orang yang bekerja dibidang perhotelan (Sandywarman 2015) .

Menurut P4B (1990:2) “Sebagian besar kejadian pencemaran makanan disebabkan oleh tidak terpeliharanya sanitasi dan hygiene dari pekrja yang terlibat dalam pengolahan makanan"

Agar standar makanan yang dihasilkan baik, maka perlu diperhatikan suatu cara yang menyangkut berikut :

(1) Standart recipe

Tujuan dari penggunaan standart recipe yaitu untuk menyeragamkan seluruh hasil pengolahan makanan dalam segi rasa atau kulitas untuk setiap jenis makanan.

(2) Standart temperatur pengolahan makanan

Tujuan daripada standart pengolahan makanan yaitu untuk memperoleh hasil pengolahan makanan dengan tetap menyangkut kualitas serta warna dan gizinya.

\section{METODE}

Sesuai dengan permasalahan yang ada maka dalam hal ini penulis akan menjelaskan mengenai hal yang berhubungan dengan personal hygiene dalam meningkatkan kualitas makanan di Restaurant Hotel Kartika Wiajaya.

1. Variabel $X$

Variabel Independent adalah variabel yang mempengaruhi keberadaan Y. Variabel $\mathrm{X}$ disini adalah Personal Hygiene

2. Variabel $Y$

Variabel Dependent adalah variabel yang keberadaannya dipengaruhi oleh keadaan yang mempengaruhinya, biasanya 
disebut variabel terikat atau variabel tergantung. Variabel $\mathrm{Y}$ disini adalah meningkatkan kualitas makanan.

Ruang lingkup dalam penelitian ini yaitu pada area kitchen dan staffnya. Sedangkan fokus pembahasan adalah peranan personal hygiene dalam meningkatkan kualitas makanan di Restaurant Hotel Kartika Wijaya Batu.

Lokasi penelitian ini dilakukan di Hotel Kartika Wijaya Batu yang terletak di Jl. Panglima sudirman No.127, Kota Batu, Jawa Timur. Nomor Telepon (0341) 592600, khususnya pada Departement Food and Beverage Product yaitu kitchen.

Sumber data penelitian ini meliputi data primer yaitu data yang diperoleh secara langsung dari sumber pertama di tempat penelitian yaitu melalui kuesioner atau pertanyaan-pertanyaan yang di berikan kepada responden dan observasi dan data sekunder adalah data yang diperoleh penulis dari hotel secara langsung atau perpustakaan atau buku referensi yang berhubungan dengan bidang yang di teliti dimana data tersebut di pergunakan untuk mendukung data premier.

Dalam hal ini penulis mengumpulan data yang diperoleh dari berbagai pihak dengan cara :

1. Teknik

Observasi

(Pengamatan)

Pengumpulan data dengan mengamati secara langsung objek penelitian dan mencatat hal-hal yang dilihat, sehingga dapat memahami jenis kegiatan serta proses kerja objek yang diamati.

2. Quesioner (Angket)

Pengumpulan data dengan cara memberikan daftar pertanyaan kepada responden untuk diisi.

\section{Kepustakaan}

Pengumpulan data yang dilakukan dengan cara membaca hasil-hasil penelitian sebelumnya terkait dengan masalah yang diteliti pada beberapa laporan akhir, artikel, makalah dan jurnal maupun bukubuku acuan tentang konsep-konsep yang menunjang dan relevan terkait dengan masalah yang diteliti. 
Penelitian ini menggunakan analisis deskriptif kualitatif data yang dalam penjabarannya mengenai penerapan personal hygiene dalam meningkatkan kedisiplinan kerja karyawan kitchen Hotel Kartika Wijaya Batu.

\section{HASIL DAN PEMBAHASAN}

Penyebab masalah yang terjadi pada staff kitchen yaitu penerapan personal hygiene dalam meningkatkan kualitas makanan di Restaurant Hotel Kartrika Wijaya Batu. Sebagai contoh salah satu seorang staff kitchen tidak memperhatikan kebersihan kuku dan tidak memakai chef hat.

Kurangnya kedisiplinan karyawan kitchen dikarenakan pengetahuan personal hygiene yang masih kurang . Sehingga akan berpengaruh terhadap kenyamanan dalam bekerja bagi setiap karyawan kitchen tersebut.

Dalam bukti masalah penulis menyajikan dalam bentuk data setelah mengetahui permasalahan yang timbul. Perananpersonal hygiene dalam meningkatkan kualitas makanan di Restaurant Hotel Kartika Wijaya Batu adalah sebagai berikut :

1. Memprioritaskan pelatihan tentang personal hygiene.

2. Evaluasi kerja secara rutin pada kayawan kitchen yang dilakukan oleh supervisor ataupun food and beverage manager.

3. Kesadaran diri dari karyawan kitchen.

\section{Evaluasi Alternatif Pemecahan Masalah}

1. Kelebihan

Jika telah ada kesadaran dari diri karayawan kitchen sendiri mengenai personal hygiene maka akan meningkatkan kedisiplinan kerja di hotel.

Kemudian dengan pelatihan secara rutin karyawan kitchen akan lebih kompeten dalam bekerja serta pelaksanaan evaluasi minimal sebulan sekali akan dapat mengoreksi kesalahan atau masalahmasalah yang terjadi selama bekerja. 


\section{Hasil Yang Diharapkan}

Sesuai dengan akibat masalah dan alternatif pemecahan masalah yang ada, peneliti berharap ada kesadaran diri dari karyawan kitchen itu sendiri dengan terciptanya personal hygiene dalam bekerja dapat terwujud sehingga dapat meningkatkan kedisiplinan kerja karyawan di hotel.

\section{KESIMPULAN dan SARAN}

\section{Kesimpulan}

Kesimpulan yang dapat

diambil peneliti setelah melakukan penelitian, adalah kurangnya penerapan personal hygiene sehingga berpengaruh terhadap kualitas makanan di Restaurant. Sehingga perlu adanya kesadaran diri dari karyawan kitchen itu sendiri untuk bekerja dengan lebih baik dan ketegasan dari supervisor atau food and beverage manager dalam memberikan pelatihan atau bimbingan yang rutin sehingga dapat meningkatkan kedisiplinan kerja karyawan di hotel.

\section{Saran}

1. Bagi perusahaan

a. Food and Beverage Manager

Diharapkan agar dapat memberikan bimbingan secara tegas kepada karyawan kitchen tentang personal hygiene dalam bekerja agar lebih dapat meningkatkan kedisiplinan kerja.

b. Karyawan Kitchen

Dapat mengikuti semua pelatihan dan bimbingan yang diberikan atasan agar dapat bekerja dengan nyaman dan tenang.

2. Bagi Lembaga

Diharapkan dapat menerapkan personal hygiene ketika praktek di kampus agar mahasiswa dapat bekerja dengan disiplin dan percaya diri di dunia kerja.

\section{DAFTAR PUSTAKA}

Anonimous. 1990. Kitchen Production. Akademi Pariwisata Denpasar 1990., Denpasar.

Anonimous. 1990. Safety Sanitasion and Hygiene. Bandung. 
Kotler, Amstrong. 2012. Quality of Food. Gramedia Pustaka: Jakarta.
Margaretha, Edwin. 2012. Kualitas Makanan. Surabaya 